\title{
Prefácio/Preface
}

\section{Em Homenagem a Mattoso Câmara (1904-1970)}

\author{
(In Honour of Mattoso Câmara (1904-1970)
}

\author{
Aryon Dall'Igna Rodrigues \\ (Universidade de Brasília)
}

A historiografia da lingüística no Brasil tem-se desenvolvido significativamente nos últimos quinze anos, particularmente depois da publicação da tese de Cristina Altman, A pesquisa lingüística no Brasil (1968-1988) (São Paulo: Humanitas, 1998). Tem-se desenvolvido tanto o estudo do passado mais remoto, o que corresponde ao período colonial, quanto o exame da produção mais recente. O presente livro, organizado pela historiógrafa Altman, reúne nove ensaios escritos para comemorar os cem anos do nascimento de Joaquim Mattoso Câmara Júnior, o inaugurador da lingüística científica no Brasil.

Como lingüista, Mattoso Câmara Jr. foi um self made man. Chegou à idade dos estudos universitários na década de 1920, quando no Brasil não havia nenhuma universidade, mas apenas faculdades profissionalizantes. Fez o curso superior de arquitetura, que lhe permitiu obter uma colocação profissional no departamento de águas da prefeitura do então Distrito Federal, o Rio de Janeiro. Em seguida fez o curso de direito, mas aparentemente nunca exerceu atividades profissionais nessa área. Paralelamente, seu pendor pelas línguas levou-o a ensinar Português e Inglês em escolas particulares do Rio de Janeiro e no Instituto de Educação, que era o centro de formação de professores para o ensino fundamental. Antes da criação das primeiras faculdades de Letras em São Paulo e no Rio de Janeiro os principais estudiosos das línguas e das literaturas ensinavam nas escolas secundárias, e sua formação lingüística ou literária era autodidática. Por essa razão, tanto na Universidade de São Paulo, a partir de 1934, como na Universidade do Distrito Federal, a partir de 1935, foram convidados especialistas do exterior para dar início ao ensino superior nessas áreas do conhecimento. E foi para substituir um desses especialistas na área lingüística, o francês Georges Millardet, que - aliás por indicação deste mesmo - foi contratado Mattoso Câmara Jr., que então desenvolveu na UDF o seu curso de lingüística geral, publicado pela primeira vez em 1941 (Princípios de Lingüística Geral como Fundamento para os Estudos Superiores da Lingua Portuguesa, Rio de Janeiro: F. Briguiet) e que veio a ser por muitos anos o 
melhor tratado de lingüística não só no Brasil, mas em todo o mundo latino conforme a visão crítica de Eugenio Coseriu, titular de lingüística da Universidade de Tübingen ("General perspectives" in Thomas Sebeok (org.), Current trends in linguistics IV: Ibero-American and Caribbean linguistics. Haia: Mouton, 1968). Somente após a publicação dessa obra é que teve sua primeira oportunidade de sair do Brasil e, nos Estados Unidos, conheceu não só um dos maiores lingüistas americanos, Leonard Bloomfield, como um dos principais lingüistas europeus, Roman Jakobson. Com este último estabeleceu relações de amizade e de afinidade intelectual mais estreitas, que duraram até o fim de sua vida, e que revelou nitidamente em sua obra subseqüente.

O espectro de interesses lingüísticos de Mattoso Câmara Jr. era muito amplo, abrangendo tanto a interpretação sincrônica do Português, como o seu desenvolvimento diacrônico, e estendendo-se também para as línguas indígenas. Os depoimentos e ensaios escritos para este livro por lingüistas que foram seus alunos ou que conviveram com ele em outras circunstâncias ou mesmo só o conheceram através de suas publicações, são em parte testemunhos e em parte análises de aspectos de sua produção científica que, passados já mais de trinta anos de sua morte, reafirmam a importância que ele teve como pesquisador, como renovador dos estudos sobre a língua portuguesa e como disseminador da ciência da linguagem no Brasil.

Esta coleção de ensaios constitui, portanto, uma nova contribuição para a historiografia da lingüística no Brasil. Ao prefaciá-la, atendendo a gentil pedido de sua organizadora, parece-me pertinente lembrar que Mattoso Câmara Jr. foi também, ele mesmo, um dos pioneiros da historiografia lingüística em nosso país. Por um lado, em sua Introdução às Linguas Indígenas Brasileiras (Rio de Janeiro: Museu Nacional, 1965), elaborou dois capítulos em que procurou historiar os estudos sobre os idiomas indígenas: "Os estudos lingüísticos no passado. A tupinologia" e "Os estudos lingüísticos no passado. A pesquisa etnológica". Por outro lado, produziu uma série de artigos sobre o perfil de alguns dos principais estudiosos da língua portuguesa no Brasil: João Ribeiro, Manuel Said Ali, Antenor Nascentes. Esse seu interesse historiográfico manifestou-se mais vivamente na produção do livro História da Lingüística (Petrópolis: Vozes, 1975), escrito originalmente em inglês para um curso dado na Universidade de Washington, em Seattle, mas também em outros trabalhos, como sua comunicação ao Simpósio de Cartagena, intitulada "Panorama da evolução da lingüística nos Estados Unidos da América” (El Simpósio de Cartagena, Bogotá: Instituto Caro y Cuervo, 1965) ou de outra apresentada pouco depois, em 1966, no I Seminário de Lingüística de Marília, SP, sobre "O estruturalismo lingüístico" (Tempo Brasileiro 15/16:5-42, Rio de Janeiro, 1967) 